\title{
An outbreak of pleural mesothelioma and chronic fibrosing pleurisy in the village of Karain/Ürgüp in Anatolia
}

\author{
Y. I. BARIS, A. A. SAHIN, M. OZESMI, I. KERSE, E. OZEN, B. KOLACAN, \\ M. ALTINÖRS, AND A. GÖKTEPELI
}

From the Departments of Chest Diseases, Histology, and Pathology, Hacettepe University School of Medicine, and the Institute of Mineral Research and Exploration, Ankara, Turkey

Baris, Y. I., Sahin, A. A., Ozesmi, M., Kerse, I., Ozen, E., Kolacan, B., Altinörs, M., and Göktepeli, A. (1978). Thorax, 33, 181-192. An outbreak of pleural mesothelioma and chronic fibrosing pleurisy in the village of Karain/Ürgüp in Anatolia. The 575 inhabitants of the remote Anatolian village of Karain suffered 11 deaths from pleural mesothelioma in 1975/76 and there were five cases of fibrosing pleurisy. In the previous five years there had been 25 cases of mesothelioma. Calcified pleural plaques were common on survey radiography. Asbestos does not occur in the local soil or rock, nor is it handled in the village, but a few fibres were found in the water. Fibres were also found in the pleural tissue of two of five cases examined. Inhabitants of the neighbouring villages are free of mesothelioma.

Karain is a village of $\mathbf{5 7 5}$ inhabitants lying in the district of Úrgüp, well known to tourists because of the picturesque rock dwellings called 'fairy chimneys'.

For a long time it has been known that the people of Karain die of cancer. The saying goes that 'The peasant of Karain falls ill with pain in the chest and belly, the shoulder drops, and he dies'.

This paper describes an investigation of the disease which has given the village this reputation. The investigation is divided into two parts: 1 . An analysis of information already available up to 1975 ; and 2 . A survey of conditions in 1975/76.

\section{Methods}

1. ANALYSIS OF INFORMATION AVAILABLE UP TO 1975 For the period up to 1970 elderly residents and the village headman (Muhtar) were the main sources of information as a formal health service had not been established in this area. More recent medical information was obtained from the Health Institute in Karain and from relatives. Information was obtained from hospitals about patients admitted from the village. Survey radiographs $(70 \times 70 \mathrm{~mm})$ taken in 1971 and information on all deaths between 1970 and 1974 were reviewed.
2. SURVEY OF CONDITIONS IN $1975 / 76$

A team of physicians, geologists, physicists, and mining and agricultural experts visited the area.

(a) They studied the physical and economic structure of the village, the working and living patterns of the inhabitants, the rock, the soil, and the water. Geological, biological, and chemical tests were done to detect toxic hazards in the environment. The tests were also applied to the neighbouring villages and the findings were compared.

(1) Airborne dust was collected on membrane filters. These and the samples of soil, rock, stucco, etc. were examined by optical and electron microscopy. Elemental analysis of soil and rock was carried out using optical spectrographic analysis, and a scintillometre model, Saphymostel, Spp 2-nf, was used to detect radioactivity.

(2) Samples of food and drink were examined for aflotoxin using the AOAC 26 Natural Poisons 20.0.14-CB (Published by the Association of Official Analytical Chemists, PO Box 540, Benjamin Franklin Station, Washington, DC 20044, USA). Soil and dust samples were extracted with cyclohexane and the extracts were examined spectrographically for benzpyrene.

(3) The water supplies were tested for nitrosamine using Preussman's reagents (Preussman and Eisenbrad, 1972). 
(4) The water supplies were also analysed for fibrous minerals; $250 \mathrm{ml}$ samples of water were filtered through a Sartorius membrane filter (Sartorius membrane filter Gmbh 3400 Göttingen Postfach 142) to collect particles of over 0.2 millimicrons. The filter was then ashed to $450^{\circ} \mathrm{C}$ for three hours and the residue was resuspended in $1 \mathrm{ml}$ distilled water by ultrasonic vibration for 30 minutes. One drop was taken onto an EM grid for examination by transmission microscopy.

(b) The team studied the health of the villagers and that of the inhabitants of neighbouring villages.

(1) The mass chest radiographic survey previously carried out in 1971 using $70 \times 70 \mathrm{~mm}$ films was repeated in 1975 . Identification of the individuals surveyed in 1971 was incomplete so that this was not an individual follow-up study.

(2) All patients developing symptoms of chest disease during 1975 and 1976 were investigated. When possible they were admitted to hospital and submitted to the usual radiological and other tests to find other primary sites of malignancy beside the pleura. Tests for delayed hypersensitivity were carried out with streptokinase-dornase, purified protein derivative, mumps, and Candida antigens. Lymphocyte counts and lymphocyte stimulation tests were also carried out on six of the patients. Histological material was obtained from patients suspected of pleural mesothelioma by punch biopsy, thoracoscopy, or thoracotomy. When underlying lung was obtained this was examined for asbestos and asbestos bodies by optical and electron microscopy. Pleural tissue from some cases was ashed and analysed by electron probe for asbestos and other minerals. Explant tissue culture from some of the biopsy material was attempted without success.

(3) The causes of all deaths in Karain and in the neighbouring villages in these two years were recorded and verified as far as possible.

The pedigrees of all new cases were investigated for evidence of inherited factors. Occupational and domestic histories were taken and investigated.

\section{Results}

1. ANALYSIS OF INFORMATION AVAILABLE UP TO 1975 The elderly residents admitted that the painful disease had been occurring in the village for many years. They said that because of it the village had always been known as Karain, which in Turkish means 'Abdominal pain'. However, records of the numbers of cases had been kept only since the establishment of a 'health institute' in the village.
The villagers recalled that the disease affected the $\stackrel{\overrightarrow{\bar{S}}}{\stackrel{\overrightarrow{7}}{9}}$ middle-aged of both sexes, and that the onset was? usually with insidious breathlessness, less often $\frac{\bar{\sigma}}{\bar{D}}$ with pain or cough. It was fatal.

More recent information from medical records $\stackrel{D}{\circ}$ showed that the disease was usually associated $\%$ with a serofibrinous or serohaemorrhagic pleural $\overrightarrow{ }$ effusion. Tests for tuberculosis were negative. Chest radiographs also showed an effusion of ten $\overrightarrow{\vec{\omega}}$ with confluent peripheral nodular shadows suggesting a mesothelioma of the pleura. In two cases $\overrightarrow{\vec{x}}$ pleural calcification was also present (Fig. 1).

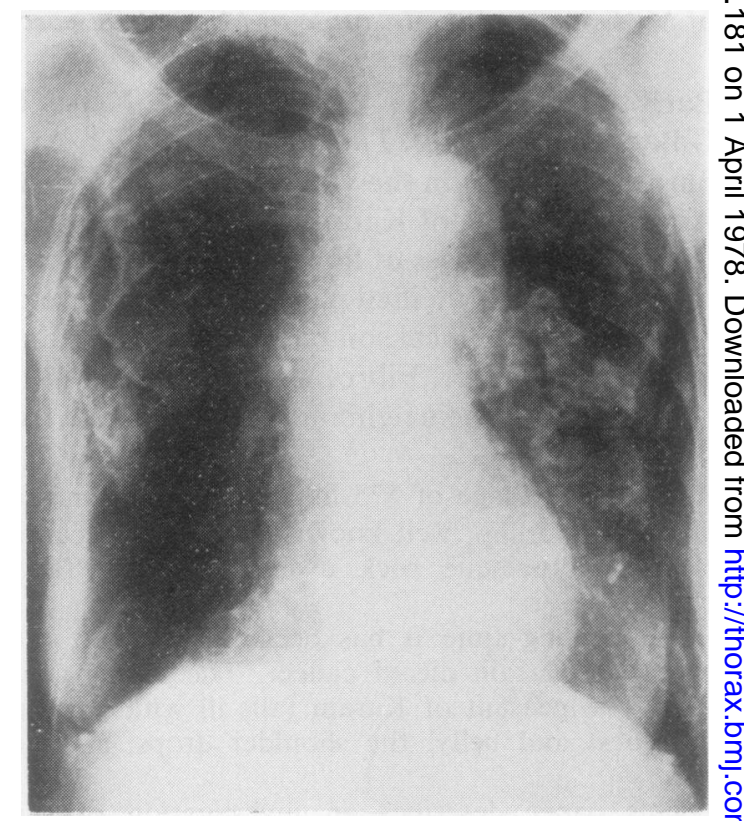

Fig. 1 Radiograph of an old woman from Karain showing multiple bilateral calcified pleural plaques.

Antituberculosis and other forms of treatment tried up to 1975 had been ineffective. N

The incidence of the disease had been high (Table 1) and appeared to account for the very high overall death rate for a village of this size. $\omega$ The situation was particularly bad in 1974 when, in a population of only 604 , there were 11 pleurale
mesotheliomas out of a total of 18 deaths.

The comparison with neighbouring villages for $\stackrel{?}{?}$ the year 1974 is shown in Table 2. The total num- $\frac{0}{0}$ ber of deaths in Karain is high but not significantly higher than in the village of Akcaören. But these $\stackrel{?}{+}$ two villages have a significantly higher death rate 2 than the rest $\left(x^{2} \quad 30.458\right.$ degrees of freedom). However, the really significant difference lies in 8 the causes of death. Whereas there were 11 pleurato 
Table 1 (a) Deaths due to malignant disease in Karain 1970-74

\begin{tabular}{llllll}
\hline & & \multicolumn{4}{l}{ Deaths due to malignant disease } \\
\cline { 3 - 6 } Year & Population & Male & Female & Total & Mean age \\
\hline 1970 & 808 & 3 & 5 & 8 & 55 \\
1971 & 795 & 3 & 1 & 4 & 48 \\
1972 & 656 & 4 & 1 & 5 & 49 \\
1973 & 656 & 1 & 2 & 3 & 50 \\
1974 & 604 & 8 & 6 & 14 & 50 \\
\hline
\end{tabular}

(b) Cau;es of death

\begin{tabular}{lllllr}
\hline Year & $\begin{array}{l}\text { Pleural } \\
\text { mesothelioma }\end{array}$ & Ca. lung & $\begin{array}{l}\text { GI } \\
\text { cancer* }\end{array}$ & $\begin{array}{l}\text { Non- } \\
\text { malignant }\end{array}$ & Total \\
\hline 1970 & 6 & 1 & 1 & 2 & 10 \\
1971 & 2 & 1 & 1 & 5 & 9 \\
1972 & 3 & 1 & 1 & 7 & 12 \\
1973 & 2 & 0 & 1 & 3 & 6 \\
1974 & 11 & 0 & 3 & 4 & 18 \\
\hline
\end{tabular}

*May have included primary peritoneal mesothelicmas.

$\dagger$ Infantile deaths, cardiovascular diseases, and accidents.

mesotheliomas in Karain there was none in any of the other villages. A number of gastrointestinal deaths occurred without a precise diagnosis and these may have included peritoneal mesotheliomas.

The 564 photofluorograms taken in 1971 were reviewed and the findings are shown in Table 3. These indicate that there has been no significant change in the general pattern of chest disease in the village since 1971 .
Table 3 Radiological findings on mass survey 1971 and 1975 compared $(70 \mathrm{~mm}$ films $)$

\begin{tabular}{lcr}
\hline & \multicolumn{2}{c}{ Number of cases } \\
\cline { 2 - 3 } Finding & 1971 & 1975 \\
\hline Diffuse fibrosis & 21 & 24 \\
Pleural tumour & 7 & 5 \\
Pulmonary tubercle & 7 & 3 \\
Carcinoma of lung & 4 & 0 \\
$\begin{array}{l}\text { Pleural calcification similar to that seen } \\
\text { in asbestos exposure }\end{array}$ & 2 & 2 \\
$\begin{array}{l}\text { Pleural and pulmonary calcification } \\
\quad \text { which resembles healed Tb, empyema, }\end{array}$ & & \\
$\quad$ or haemothorax & 2 & 2 \\
Pleural thickening & 0 & 3 \\
Films taken & 564 & 452 \\
\hline
\end{tabular}

\section{SURVEY OF CONDITIONS IN $1975 / 76$}

(a) The environment

The village of Karain lies in Cappadocia in central Anatolia (Fig. 2). Rock consists of volcanic tuffs. The soil is poor, and the climate very hot and dry in summer and cold with snow in winter. The soft volcanic rock is cut by adze for making walls of houses and buildings and is plastered with a greyish-white powdered rock from the neighbouring hills. Similar powdered material is used for clearing wine and making a sweetmeat called 'pekmez'. Most people work on the land growing potatoes and onions in the area between the village and the river. The work is very dusty and hot in summer. Apart from a few donkeys, mules, dogs, and poultry, no animals are kept and few fodder crops are grown.

Table 2 Comparison of deaths in Karain and neighbouring villages, 1974

\begin{tabular}{|c|c|c|c|c|c|c|c|c|}
\hline \multirow[b]{2}{*}{ Village } & \multirow{2}{*}{$\begin{array}{l}\text { Distance } \\
\text { from } \\
\text { Karain }(\mathrm{km})\end{array}$} & \multirow[b]{2}{*}{ Population } & \multicolumn{2}{|c|}{ Total no. of deaths } & \multicolumn{4}{|l|}{ Cause of death } \\
\hline & & & Obs. & Exp. & $\begin{array}{l}\text { Pleural } \\
\text { mesothelioma }\end{array}$ & $\begin{array}{l}\text { GI } \\
\text { disease }\end{array}$ & Infantile & Other \\
\hline Karain & 0 & 604 & 18 & $6 \cdot 60$ & 11 & 3 & 1 & $\begin{array}{l}1 \text { accident } \\
2 \text { stroke }\end{array}$ \\
\hline Akcaören & 20 & 544 & 11 & 5.94 & $\mathbf{0}$ & 2 & 9 & 0 \\
\hline Akkoy & 9 & 972 & 6 & $10 \cdot 62$ & $\mathbf{0}$ & 0 & 2 & $\begin{array}{l}2 \text { cardiac } \\
1 \text { psychosis } \\
1 \text { accident }\end{array}$ \\
\hline Basdere & 13 & 2764 & 28 & $30 \cdot 19$ & 0 & 4 & 13 & $\begin{array}{l}2 \text { stroke } \\
1 \text { ca. lung } \\
3 \text { Tb } \\
1 \text { suicide } \\
1 \text { unknown }\end{array}$ \\
\hline $\begin{array}{l}\text { Boyali* } \\
\text { Demirtas }\end{array}$ & 3 & 530 & 3 & $5 \cdot 79$ & 0 & 1 & 1 & 1 renal disease \\
\hline Demirtas & 12 & 275 & 3 & 3.00 & 0 & 1 & 1 & $\begin{array}{l}1 \text { chronic obst. } \\
\text { lung disease }\end{array}$ \\
\hline $\begin{array}{l}\text { Iltas } \\
\text { Karlik }\end{array}$ & $\begin{array}{l}9 \\
4\end{array}$ & $\begin{array}{l}348 \\
645\end{array}$ & 2 & $3 \cdot 80$ & 0 & 1 & $\mathbf{0}$ & 1 rh. fever \\
\hline & & & 5 & $7 \cdot 04$ & $\mathbf{0}$ & 1 & 2 & $\begin{array}{l}1 \text { cardiac } \\
1 \text { unknown }\end{array}$ \\
\hline Yesilöz† & 7 & 641 & 4 & $7 \cdot 00$ & 0 & 0 & 2 & $\begin{array}{l}1 \text { cardiac } \\
1 \text { genitourinary } \\
\text { disease }\end{array}$ \\
\hline
\end{tabular}

*One patient from Boyali died of mesothelioma in 1976. She was a native of Karain and lived there until she was 25 years old (Table 4, case 11).

†A patient migrated to Yesilöz from Karain when she was 12 years old. She was found to have a mesothelioma in 1976, aged 52 (Table 4, case 13). 


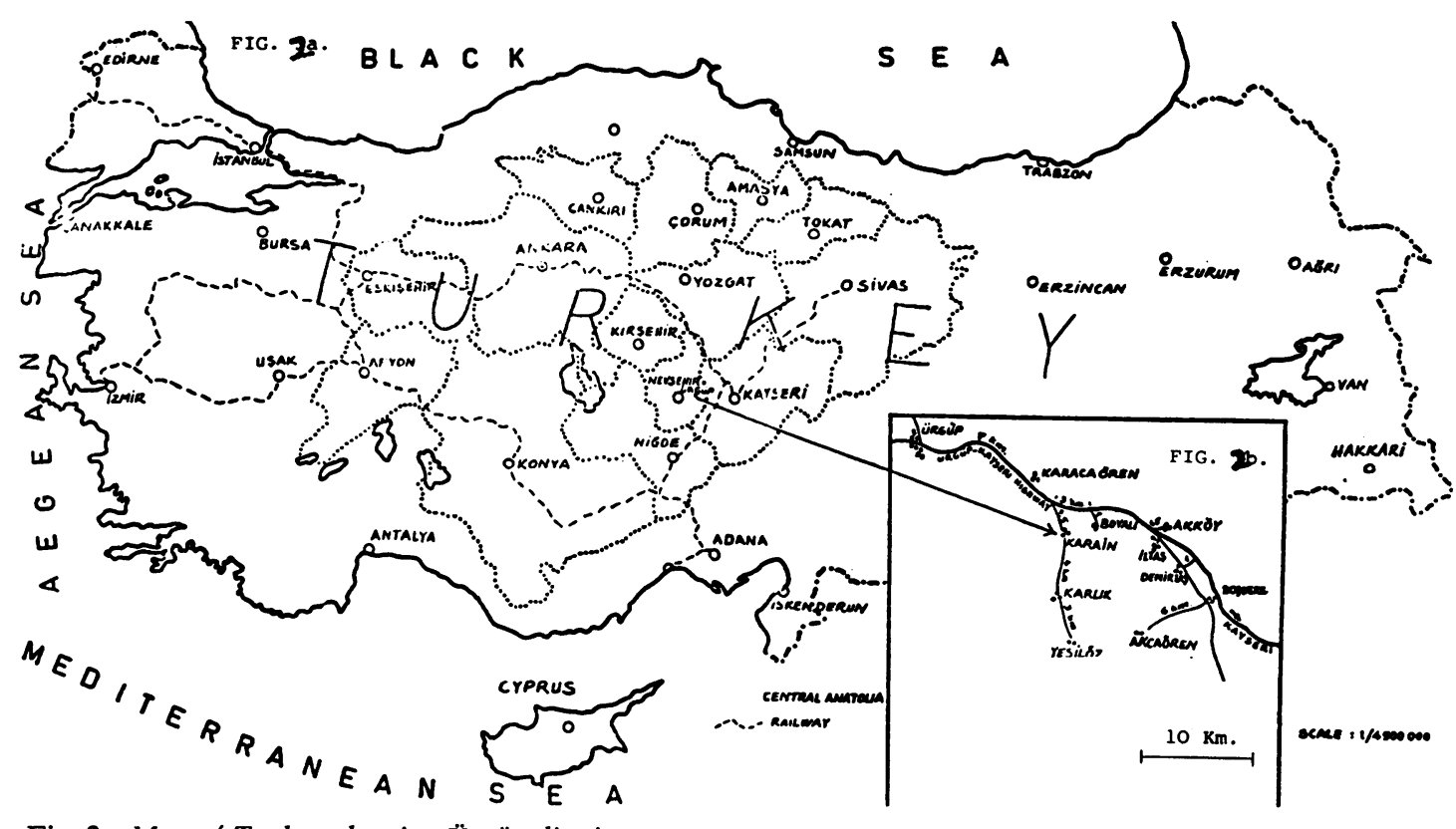

Fig. 2 Map of Turkey showing Ürgüp district.

In Karain some of the men are smokers; the women never smoke.

Water is obtained from: (a) the river; (b) the springs in the river bed; (c) wells in the fields; and (d) a spring in the hills behind the village which is piped to a communal tap in the village. The villagers are mainly dependent on the piped water, which has been available for over 100 years, for drinking, washing, and cooking. Recently, artesian wells have been dug close to the village and used to provide more piped water to it. None of the systems contains asbestos pipes. The other sources are used for irrigation but in hot weather the field workers drink from the wells and the springs in the river bed and all the villagers bathe in the river.

The village lies on the road up the valley (Fig. 2) to the villages of Karlik and Yesilöz. The road is not metalled and is very dusty. These villagers do not share Karain's piped water supply but are otherwise similar. Karain's disease makes it difficult for the peasants to sell their potatoes and onions so that they are even poorer than their neighbours. Young people moving from the village may develop the disease in later life; but young people moving to Karain do not develop the disease. The village population dwindles because of the economic difficulties, and the young people have to move far away to areas where the problem is not known.
There are no deposits of asbestos in the area $\stackrel{\unrhd}{\unrhd}$ nor has there been any processing of such material $\overrightarrow{0}$ brought in from elsewhere. The soil, the rock, 3 the stucco, the material used for making the sweetmeat, and the airborne dust contain volcanic debris. There are no asbestos fibres but there are a few fine barbed fibre fragments of volcanic glass.

Rock samples contained calcite, feldspar, quartz, volcanic glass, biotite, chlorite, muscovite, and augite. The main elements are silicon, alu- $\delta$ minium, and magnesium with smaller quantities of calcium and iron. Optical spectrographic analy- 응 sis did not indicate that arsenic, uranium, nickel $\supset$ or chromium were present in sufficient quantities to constitute a cancer risk.

Tests for aflotoxin on potatoes, bread, grape juice, wine, wheat, and fresh fruit used by the $\mathcal{N}$ villagers were negative. Cyclohexane extracts of $\tilde{\omega}$ soil, dust, and stucco were negative for benzpyrene.

Nitrosamine tests on various water samples $\frac{\mathbb{\Phi}}{2}$ were negative. No significant radioactivity was $\stackrel{\mathcal{P}}{?}$ found in the village or in the surrounding soil and ${ }^{\circ}$ rocks.

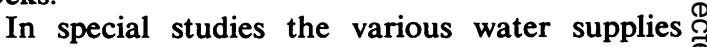
to Karain were compared with the water used in $\stackrel{\mathscr{Q}}{\Omega}$ Karlik and Yesilöz (4 and $7 \mathrm{~km}$ further up the valley). Only in the original piped supply to Karain $\delta$ and in water from one of the old wells by the 
river were any mineral fibres found (Fig. 3). There were small quantities of fibres ranging from 5 to 70 microns long.

(b) The health of the villagers

The mass radiographic survey showed no significant change in the incidence of chest disease between 1971 and 1975. But during 1975 and 1976,
16 new cases of pleural disease were found. Table 4 gives some of the details of these patients. None of the eight men and eight women had done anything but work in the fields or at home except case 7. They were between 27 and 65 years old and presented with chest pain and breathlessness.

Case 3 had been treated for pleurisy 20 years previously and the radiograph taken in 1971 had

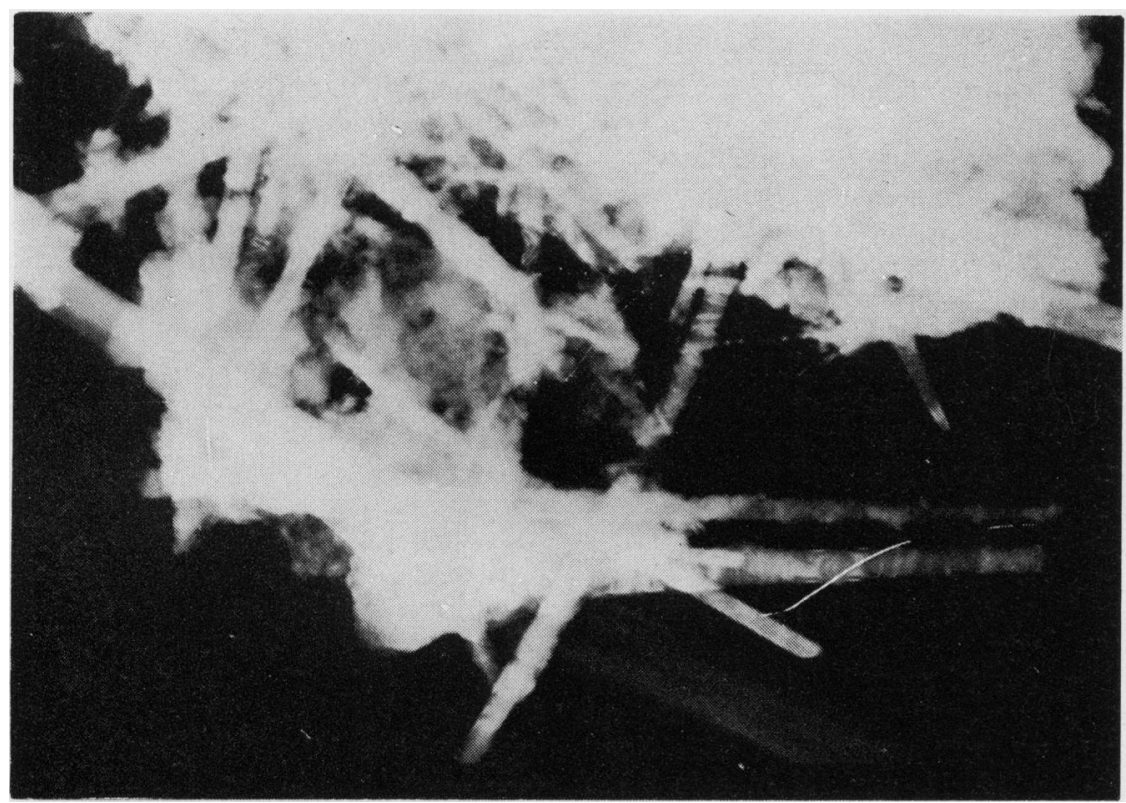

Fig. 3 Clumps of? asbestos fibres in the water of Karain. $\times 30000$.

Table 4 Prospective study of new patients in 1975 and 1976

\begin{tabular}{|c|c|c|c|c|c|}
\hline Case & $\begin{array}{l}\text { Agel } \\
\operatorname{sex}\end{array}$ & $\begin{array}{l}\text { Clinical and radiological } \\
\text { findings }\end{array}$ & $\begin{array}{l}\text { Diagnostic } \\
\text { methods }\end{array}$ & $\begin{array}{l}\text { Histopathological } \\
\text { diagnosis }\end{array}$ & Comments \\
\hline 1 & $40 \mathrm{M}$ & $\mathbf{R}$ massive haem. pl. effusion & Thoracoscopy & Malignant pl. mesothelioma & Died $5 \mathrm{mth}$ later \\
\hline 2 & $65 \mathrm{M}$ & L massive haem. pl. effusion & Thoracoscopy & Chronic fibr. pleurisy & Died $4 \mathrm{mth}$ later \\
\hline 3 & $46 \mathrm{M}$ & L pl. effusion & Thoracotomy & Chronic fibr. pleurisy & Pleurectomy. Well \\
\hline 4 & $50 \mathrm{~F}$ & $R$ pl. effusion & Pl. punch biopsy & Chronic fibr. pleurisy & Died $2 \frac{1}{2}$ yr later \\
\hline 5 & $60 \mathrm{~F}$ & $\mathbf{R}$ massive haem. pl. effusion & P1. punch biopsy & Malignant pl. mesothelioma & Died 4 mth later \\
\hline 6 & $50 \mathrm{~F}$ & $\begin{array}{l}\mathbf{R} \text { pl. thickening and } \\
\text { peripheral nodular pulm. } \\
\text { lesions }\end{array}$ & Radiology & - & Died 5 mth later \\
\hline 7 & $37 \mathbf{M}$ & L pl. effusion & Thoracotomy & $\begin{array}{l}\text { Chronic fibr. pleurisy } \\
\text { Malignant pl. mesothelioma }\end{array}$ & $\begin{array}{l}\text { Pleurectomy. L L } \\
\text { lobectomy. Well }\end{array}$ \\
\hline 8 & $48 \mathrm{~F}$ & L pl. effusion & Thoracoscopy & Malignant pl. mesothelioma & Died 2 yr later \\
\hline 9 & $50 \mathrm{M}$ & $\mathbf{R}$ pl. thickening with effusion & Pl. punch biopsy & Malignant pl. mesothelioma & Died $8 \mathrm{mth}$ later \\
\hline 10 & $43 \mathrm{~F}$ & $\mathbf{R}$ pl. effusion & P1. punch biopsy & Malignant pl. mesothelioma & Died $2 \frac{1}{2}$ yr later \\
\hline 11 & $63 \mathrm{~F}$ & $\begin{array}{l}\text { L pl. thickening and } \\
\text { peripheral nodular pulm. } \\
\text { lesions }\end{array}$ & Thoracotomy & Malignant pl. mesothelioma & Died $4 \mathrm{mth}$ later \\
\hline 12 & $45 \mathrm{M}$ & $\begin{array}{l}\text { L pl. thickening and } \\
\text { peripheral pulm. nodule }\end{array}$ & Radiology & - & 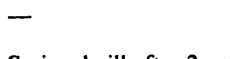 \\
\hline 13 & $52 \mathrm{~F}$ & $\begin{array}{l}\mathrm{R} \text { pl. effusion with } \\
\text { peripheral pulm. lesions }\end{array}$ & Thoracoscopy & Malignant pl. mesothelioma & Seriously ill after $2 \mathrm{yr}$ \\
\hline 14 & $50 \mathrm{~F}$ & $\begin{array}{l}\mathbf{R} \text { pl. thickening with } \\
\text { peripheral pulm. lesions }\end{array}$ & Radiology & - & Died $3 \mathrm{mth}$ later \\
\hline $\begin{array}{l}15 \\
16\end{array}$ & $27 \mathrm{M}$ & $\mathbf{R}$ hydropneumothorax & Pl. punch biopsy & Chronic fibr. pleurisy & Well \\
\hline 16 & $60 \mathrm{M}$ & R pl. thickening & Radiology & 一 & - \\
\hline
\end{tabular}


shown a left pleural effusion. At thoracotomy dark yellow fluid filled the pleural cavity and the visceral and parietal pleura was leathery and $5 \mathrm{~mm}$ thick. There were partially calcified hyaline plaques in the parietal pleura. The histological diagnosis was chronic fibrosing pleurisy and the patient remains well after pleurectomy.

Case 7 was working as a road constructor in Germany when he was investigated there in 1972 and a diagnosis of left-sided pleurisy with effusion was made. A left lobectomy and pleurectomy was performed at the Ruhrlandklinik in Essen in September 1974 to remove what was thought to be a bronchiectatic lobe secondary to the pleurisy. A histological diagnosis of malignant pleural tumour (probably mesothelioma) was made. As the patient remains well we suspect that this may have been chronic fibrosing pleurisy.

Irrespective of the histological diagnosis the radiological findings showed pleural fluid, pleural thickening, and nodular peripheral lung shadows consistent with the diagnosis of mesothelioma. The usual tests for cancer of other primary sites, for other causes of pleural effusion, and for collagen disease were all negative.

Tests for delayed hypersensitivity were performed on cases $3,7,8,10,11$, and 13 and all were negative.

The final diagnosis of mesothelioma was made in 11 of the 16 cases and was based on clinical and radiological grounds as well as on histology in cases $1,5,8,9,10,11$, and 13 . In case 2 the diagnosis of mesothelioma was made in spite of the histological findings because of the thoracoscopy appearance, the fact that there was a massive haemorrhagic effusion, and the short fatal course of the disease. The clinical and radiological findings and fatal outcome also led to the diagnosis of mesothelioma in cases 4,6 , and 14 .

The final diagnosis of chronic fibrosing pleurisy was made in the other five cases. The clinical course fitted the histological findings in cases 3 and 15. Case 7 has already been described. In cases 12 and 16 the diagnosis rests on clinical and radiological evidence.

Cases $4,6,12,14$, and 16 refused thoracotomy $\overrightarrow{\vec{x}}$ and some of the other investigative procedures.

The histological findings in case 8 are typical for mesothelioma. 'There are cuboidal cells with $\vec{\infty}$ acidophilic cytoplasm and nuclei rich in chromatin, looking like mesothelioma cells forming sheet- 은 like and adenoid structures. There is also dense mononuclear cell infiltration. Moreover there is $\frac{7}{2}$ calcification in hyalinised fibrous tissue' (Fig. 4). Histological sections from the fibrous pleurisies $\vec{\varphi}$ revealed fibrous tissue, rare mitosis, mononuclear $\stackrel{\varpi}{\infty}$ cells, and hyalinised collagen tissue. Sometimes mononuclear cell infiltration formed follicles in the fibrous tissue and there was proliferation of mesothelial cells. Amorphous iron pigment in and outside the macrophages was also seen.

Asbestos bodies could not be demonstrated in these cases by optical microscopy.

Pleural biopsies from cases 2,4 , and 5 were examined by electron microscopy. In case 2 the cells and nuclei were large with prominent nucleoli. Mitochondria were moderate in number. Smooth and rough surface endoplasmic reticulum was abundant and enlarged in many cells. The cytoplasm contained dense inorganic material in

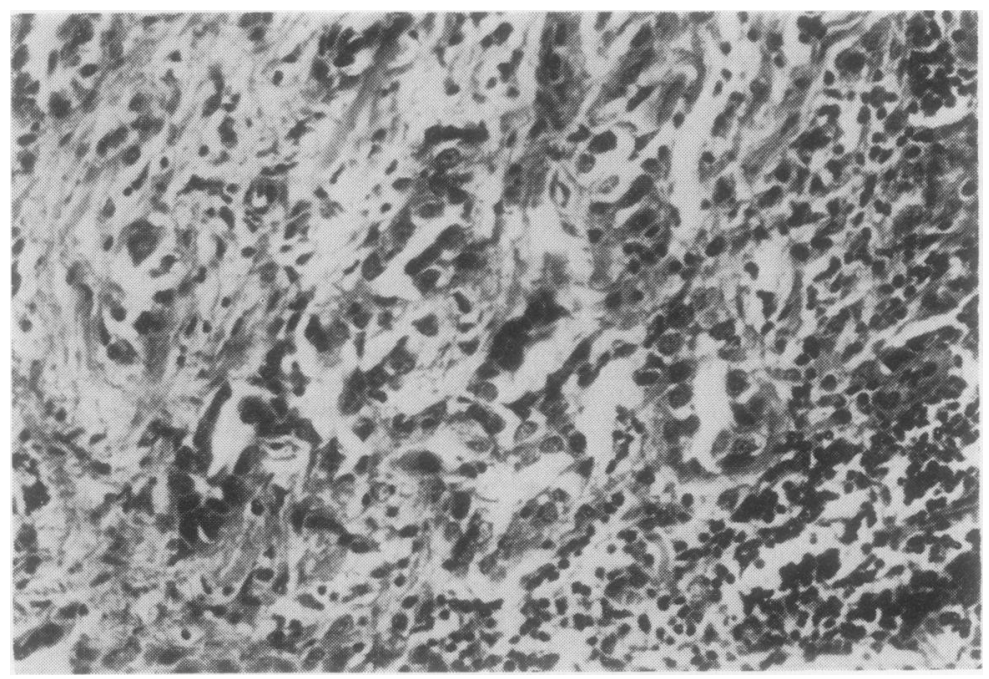

Fig. 4 Case 8. Pleural biopsy shows malignant mesothelioma. Haematoxylin and eosin $\times 300$. 
many cells (Fig. 5). In some cells ferritin could be demonstrated and tonofilaments were also visible. Most cells had the microvilli on the surface. Some other cells have shown granules varying in size and density (Fig. 6). The other two cases showed similar EM characteristics.

Electron microscopy of ashed pleural tissues from cases $1,3,8,10$, and 13 showed about 10 chrysotile fibres in case 1 . In case 3 there were $1.2 \times 10^{5}$ chrysotile and $3 \times 10^{5}$ amphibole asbestos fibres per gram of dry tissue. Traces of talc, calcium sulphate, feldspar, quartz, mica, and kaolinite were also found in the ashed tissue (Figs 7 and 8).

Genealogical surveys have proved that bloodrelationship is not a necessary prerequisite for the incidence within families. The information suggests a common environmental aetiology. For instance, in the Sencan family (Table 4) case 2 is the mother of case 3. Case 13 is the sister-in-law of case 14 but the husband of case 14 had died of a mesothelioma in 1970. Neither parent in the Sencan family had died of mesothelioma.

Cases 10, 11, and 13 had been brought up in Karain and had moved to UUrgüp, Yesilöz, and Boyali when they married and before they developed mesothelioma. Conversely, no one brought up elsewhere who came to live in Karain developed mesothelioma.

Six other inhabitants of Karain became seriously ill or died during $1975 / 76$. The results of the investigation of these patients are given in Table 5.

Table 5 Deaths in Karain 1975-76

\begin{tabular}{|c|c|c|}
\hline Case & Age/Sex & Comments \\
\hline $\begin{array}{l}17 \\
18\end{array}$ & $\begin{array}{ll}46 & M \\
65 & M\end{array}$ & $\begin{array}{l}\text { Gastric biopsy proved gastric cancer. Died } \\
\text { Presently being followed with chylous } \\
\text { ascites, chylothorax, and chronic renal } \\
\text { disease }\end{array}$ \\
\hline 19 & $75 \quad F$ & $\begin{array}{l}\text { Died from stroke. Chest radiograph show's } \\
\text { pleural calcifications (Fig. 1) }\end{array}$ \\
\hline $\begin{array}{l}20 \\
21 \\
22\end{array}$ & $\begin{array}{ll}75 & \mathrm{M} \\
61 & \mathrm{~F} \\
80 & \mathrm{~F}\end{array}$ & $\begin{array}{l}\text { Died from chronic obstructive lung disease } \\
\text { Died from rheumatic heart disease } \\
\text { Died from stroke }\end{array}$ \\
\hline
\end{tabular}

\section{Discussion}

The investigation shows that diffuse pleural mesothelioma and chronic fibrous pleurisy are endemic in Karain. The disease affects the middle-aged and elderly in some families more than in others. There is no definite evidence of a genetic factor, and the main occupation of most of those affected is agriculture. Published epidemiological studies on mesothelioma (Wagner et al., 1960; Newhouse and Thompson, 1965; Selikoff et al., 1965; McDonald et al., 1970; Rubino et al., 1972) have emphasised that environmental or occupational exposure to asbestos is the important factor although tenuous evidence of a familial incidence has been reported by Webster (1965) and Milne (1976).

There is no obvious occupational or environmental source of asbestos exposure in Karain apart from the few fibres in the water. But asbestos fibres were found in the pleural tissue of two of the five cases investigated. Pleural calcification was seen quite frequently and was typical of that resulting from asbestos exposure. No other cause for the pleural lesions was found. Only three deaths due to primary lung cancer occurred between 1970 and 1976 (all men). Primary lung cancer is common in heavily exposed asbestos workers who smoke. The women of Karain did not smoke; the men smoked locally cured tobacco.

It is a feature of most carefully investigated series of mesothelioma that they include cases with no occupational or neighbourhood exposure to asbestos (McDonald et al., 1970; Webster, 1972; Greenberg and Davies, 1974; Nurminen, 1975; Milne, 1976). It is difficult to ignore these cases although the possibility of avoiding contact with asbestos with its thousand or more occupational uses seems remote.

There are striking similarities between Rous and Studeny's survey (1970) and ours. They reported that plaques are endemic in the region of Pelhrimoy in Czechoslovakia, mainly in elderly farmers, with a familial occurrence and that pleural effusion was the common disease in their past history. Their geological survey showed that there is no asbestos in the vicinity of Pelhrimoy nor are any mines, mills or factories located there. But they failed to observe mesothelioma. However, we have found some villages in Turkey with endemic pleural calcification, and asbestos studies in these places gave negative results (Baris, 1975).

When there has been no occupational, neighbourhood, or domestic exposure to asbestos but asbestos fibres are detected in the pleural tissues of subjects with pleural plaques, with chronic fibrous pleuritis, or with diffuse mesothelioma, certain possibilities must be considered. The patient might have been exposed to asbestos from an as yet undetected source. These disorders may be caused by some unsuspected environmental agents, such as volcanic glass, talc, mica, kaolin, or feldspar. However, the same kinds of minerals have been found in other villages near Karain. The physical properties and concentration of volcanic glass and other fibres in the soil of this 


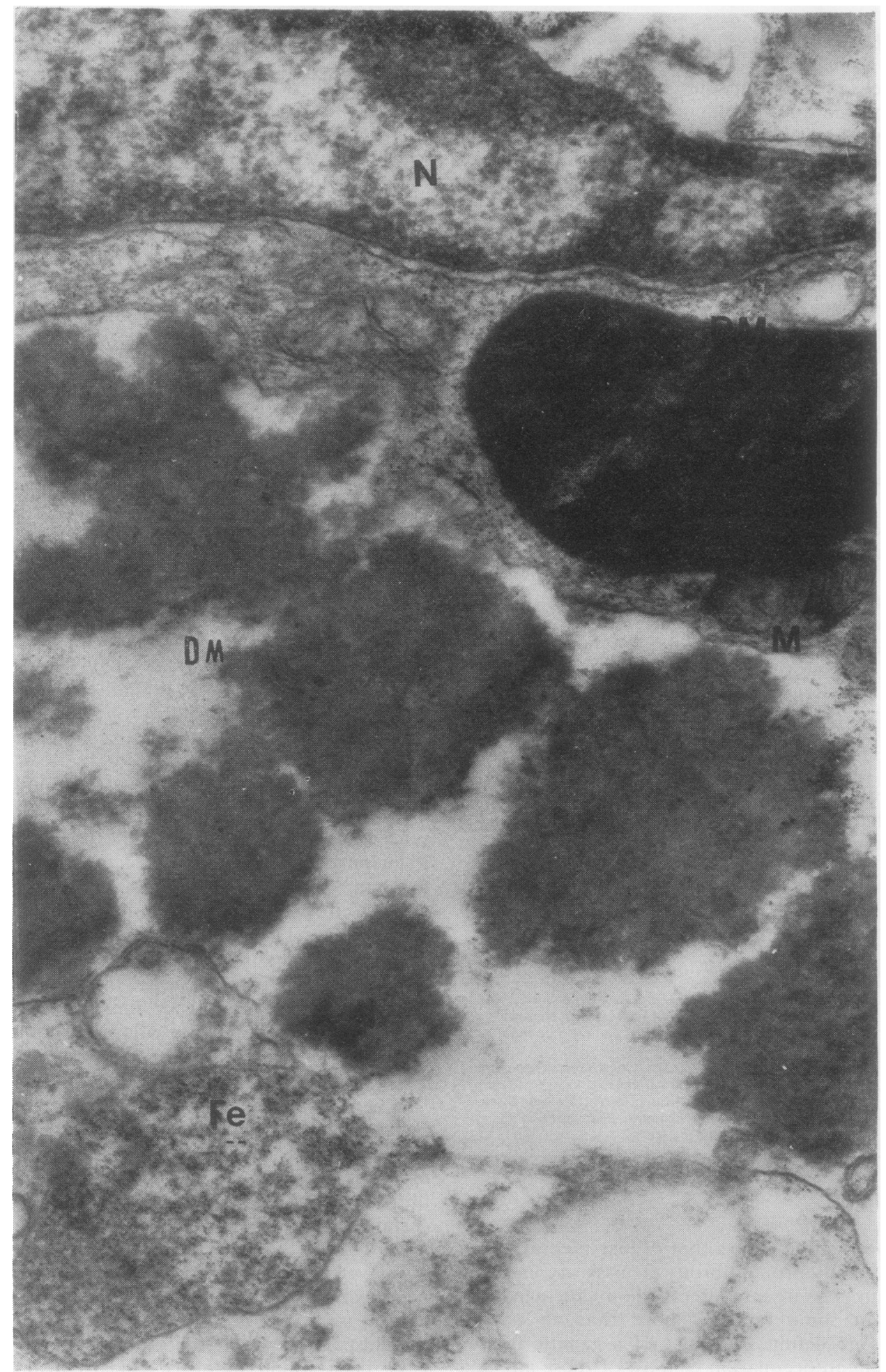

Fig. 5 Case 2. Electron microscopic view. $N$, nucleus; $M$, mitochondrium; DM, dense material; Fe, ferritin. Lead citrate-uranyl acetate. $\times 78000$. 


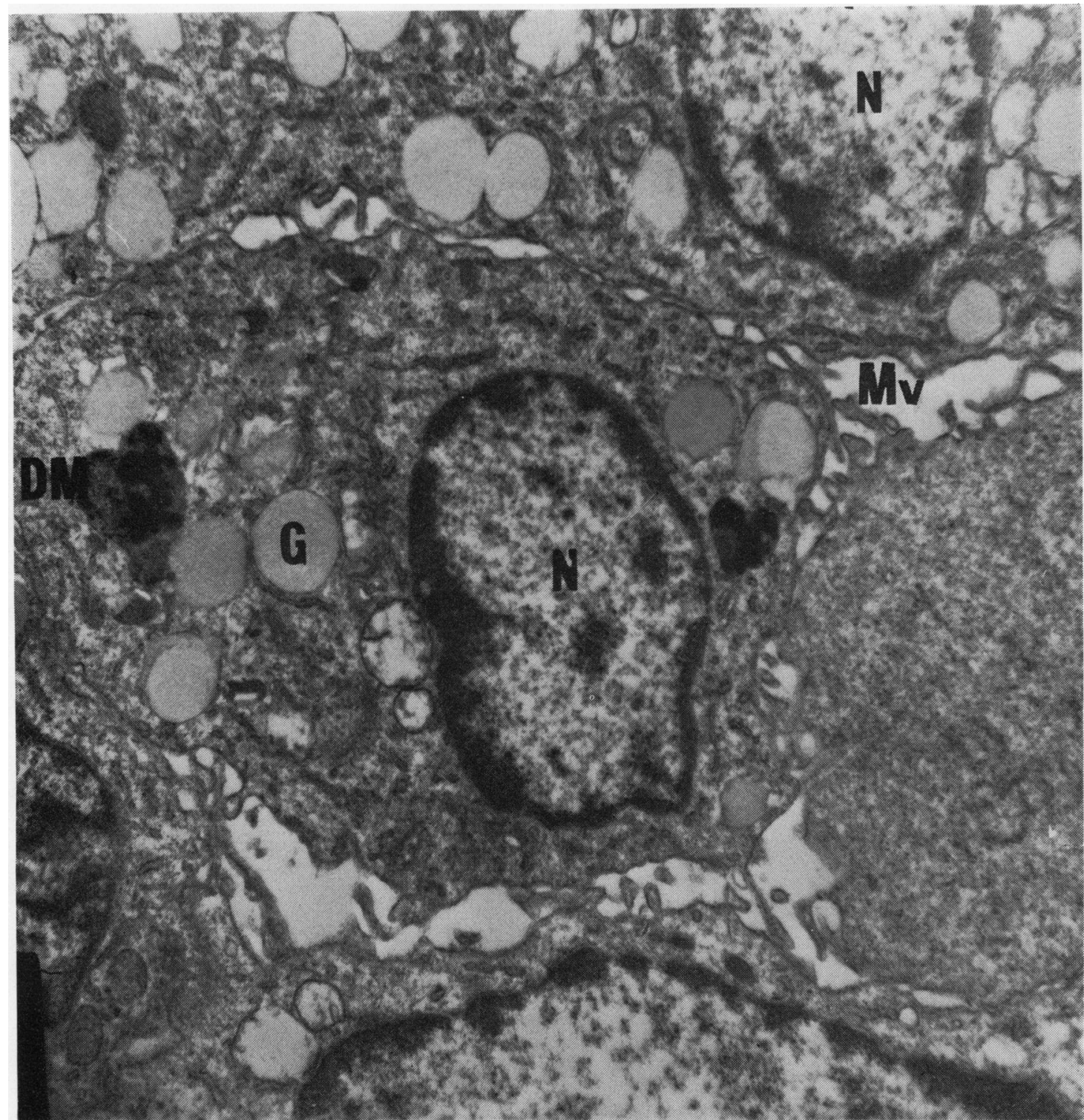

Fig. 6 Case 2. Electron microscopic view shows three mesothelial cells. $N$, nucleus; $D M$, dense material; $G$, secretory granules; $M v$, microvillus. Lead citrate-uranyl acetate. $\times 11700$.

region have not been studied analytically, and one could argue that there might be an actual difference in these particles from those in other villages. Another possibility is that the causative agent is asbestos, which reaches the body by means of water-that is, tap water, beverages, and foods are the sources of the asbestos fibres. Attention has recently been directed towards the widespread occurrence of asbestos fibres in certain natural sources and beverages (Biles and Emerson, 1968; Cunningham and Pontefract, 1971; Cook et al., 1974; Masson et al., 1974; Wells, 1975). But there is no agreement as to whether asbestos fibres in the water may be hazardous to health. Gross et al. (1974) have shown that the penetration of the ingested asbestos fibres through the walls of the gastrointestinal tract does not occur. Gross (1974) believes that the asbestos fibres in 


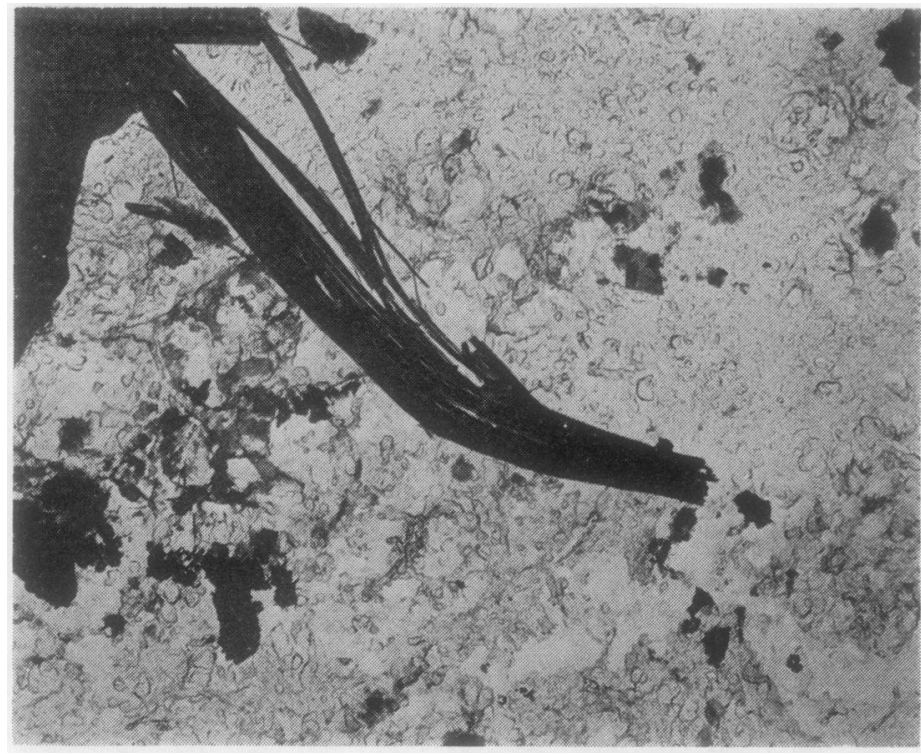

Fig. 7 Case 3. Chrysotile asbestos fibres in the ashed pleural tissue. $\times 7500$.

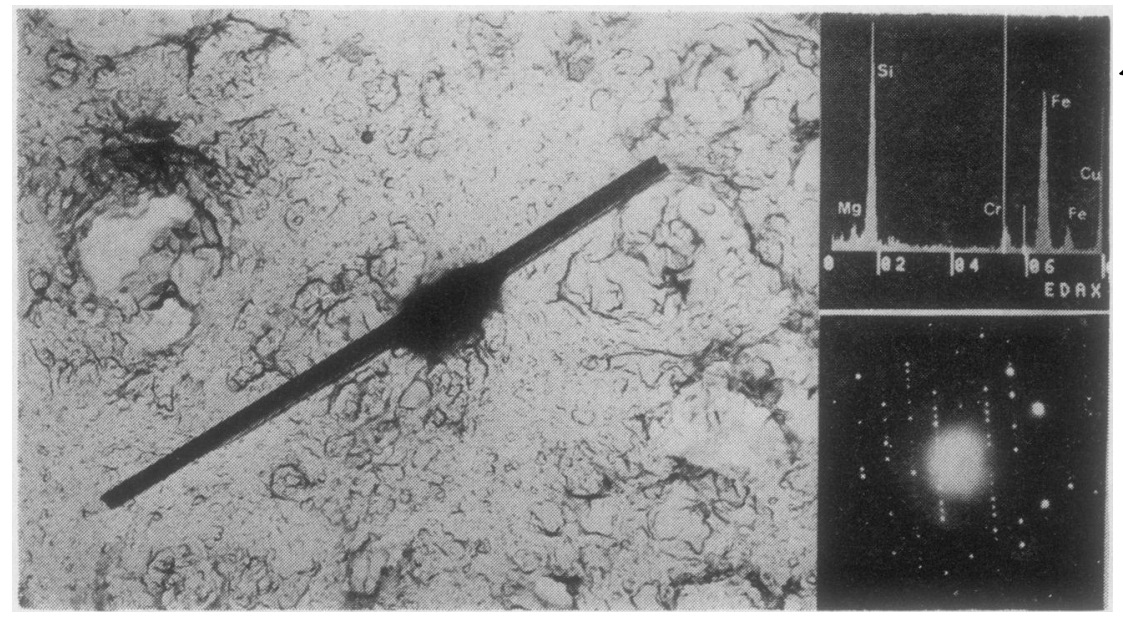

Fig. 8 Case 3. Amphibole asbestos fibres in the ashed pleural tissue. $\times 16750$.

the water and beverages are submicronic and that this kind of asbestos fibre is not carcinogenic or fibrogenic. However, some authors suggest that inoculation of asbestos fibres into the stomach results in penetration of the digestive tract by these fibres, spreading to various organs, and this condition may be important in asbestos carcinogenesis (Westlake et al., 1965; Pontefract and Cunningham, 1973). The advisory committee of the Lyon Conference (Bogovsky et al., 1973) judged there to be no evidence at present of 'an increased cancer risk resulting from asbestos fibres present in water, beverages or food or in the fluids used for the administration of drugs'. The outbreak of fibrous pleuritis and diffuse mesothelioma in $\omega$ Karain may well be an example of this route. We are unable to explain why these diseases occur in $\stackrel{O}{ᄃ}$ only one of the three villages, which are located quite close to each other and in the same valley, where the same kind of inhabitants live in the same living conditions. The only lifference between these $\underset{\mathbb{D}}{\stackrel{D}{ }}$ villages is the source of the drinking water. Pre- $\frac{?}{\mathbb{Q}}$ liminary studies of the water of Karain, which $\cong$ showed asbestiform fibres, support our view. Perhaps the natural waters of Karain may $\delta$ be derived from the wearing down of asbestos- 
containing rocks. The asbestos fibres in the water may be ingested or evaporation of the water may cause the asbestos fibres to become airborne. If our opinion is correct, asbestos in water may play a role in the pathogenesis of the endemic pleural calcification described earlier (Kiviluoto, 1960; Zolov, 1967; Burilkov and Michailova, 1970; Yazicioglu, 1976) and of certain cases of mesothelioma and chronic fibrous pleuritis whose exposure to asbestos could not be traced.

Mesothelioma has been induced by a strain MC29 Avium leucosis virus (Chabot et al., 1970). It is very difficult to accept that this could be the cause of the localised disease in Karain, which is close to two other villages.

Further studies are required, such as exact measurements of the dimension of the fibres. The range of dimensions, the percentage of the different sizes, and their chemical composition should be reported and supported by experiments which show that the natural waters of Karain induce mesothelioma or chronic diffuse pleuritis.

This study was supported by The Scientific and Technical Research Council of Turkey.

We are grateful to Drs. P. C. Elmes and J. C. Wagner, of the MRC Pneumoconiosis Unit, and to Professor P. J. Lawther and Mr. Biles, of the MRC Environmental Hazards Unit, for their help and advice. We also thank L. le Bouffant, chief of the Département Physique-Biologie Laboratoire du Centre d'Etudes et Recherches des Charbonages de France, who performed electron microscopic analysis of the tissue for asbestos.

\section{References}

Baris, Y. I. (1975). Pleural mesotheliomas and asbestos pleurisies due to environmental asbestos exposure in Turkey. An analysis of 120 cases. Hacettepe Bulletin of Medicine/Surgery, 8, 165185.

Biles, B., and Emerson, T. R. (1968). Examination of fibres in beer. Nature, 219, 93-94.

Bogovski, P., Gilson, J. C., Timbrell, V., and Wagner, J. C. (eds.) (1973). Biological Effects of Asbestos. Proceedings of a Working Conference. International Agency for Research on Cancer, Lyon

Burilkov, T., and Michailova, L. (1970). Asbestos content of the soil and endemic pleural asbestosis. Environmental Research, 3, 443-451.

Chabot, J. F., Beard, D., Langlois, A. J., and Beard, J. W. (1970). Mesotheliomas of peritoneum, epicardium, and pericardium induced by strain MC29 avian leukosis virus. Cancer Research, 30, 1287-1308.

Cook, P. M., Glass, G. E., and Tucker, J. H. (1974).
Asbestiform amphibole minerals: detection and measurement of high concentrations in municipal water supplies. Science, 185, 853-855.

Cunningham, H. M., and Pontefract, R. (1971). Asbestos fibres in beverages and drinking water. Nature, 232, 332-333.

Greenberg, M., and Davies, T. A. L. (1974). Mesothelioma register 1967-1968. British Journal of Industrial Medicine, 31, 91-104.

Gross, P. (1974). Is short-fibered asbestos dust a biological hazard? Archives of Environmental Health, 29, 115-117.

Gross, P., Harley, R. A., Swinburne, L. M., Davis, J. M. G., and Green, W. B. (1974). Ingested mineral fibers: Do they penetrate tissues or cause cancer? Archives of Environmental Health, 29, 341-347.

Kiviluoto, R. (1960). Pleural calcification as a roentgenologic sign of non-occupational endemic anthophyllite-asbestosis. Acta Radiologica, Supplement 194.

Masson, T. J., McKay, F. W., and Miller, R. W. (1974). Asbestos-like fibres in Duluth water supply. Relation to cancer mortality. Journal of the American Medical Association, 228, 1019-1020.

Milne, J. E. H. (1976). Thirty-two cases of mesothelioma in Victoria, Australia: a retrospective survey related to occupational asbestos exposure. British Journal of Industrial Medicine, 33, 115-122.

McDonald, A. D., Harper, A., El Attar, O. A., and McDonald, J. C. (1970). Epidemiology of primary malignant mesothelio tumors in Canada. Cancer, 26, 914-919.

Newhouse, M. L., and Thompson, H. (1965). Mesothelioma of pleura and peritoneum following exposure to asbestos in the London area. British Journal of Industrial Medicine, 22, 261-269.

Nurminen, M. (1975). The epidemiologic relationship between pleural mesothelioma and asbestos exposure. Scandinavian Journal of Work, Environment and Health, 1, 128-137.

Pontefract, R. D., and Cunningham, H. M. (1973). Penetration of asbestos through the digestive tract of rats. Nature, 243, 352-353.

Preussman, R., and Eisenbrad, G. (1972). Topics in Chemical Carcinogenesis, p. 323. University of Tokyo Press.

Rous, V., and Studeny, J. (1970). Aetiology of pleural plaques. Thorax, 25, 270-284.

Rubino, G. F., Scansett, G., Donna, A., and Palestro, G. (1972). Epidemiology of pleural mesothelioma in north-western Italy (Piedmont). British Journal of Industrial Medicine, 29, 436-442.

Selikoff, I. J., Churg, J., and Hammond, E. C. (1965). Relation between exposure to asbestos and mesothelioma. New England Journal of Medicine, 272, $560-565$.

Wagner, J. C., Sleggs, C. A., and Marchand, P. (1960). Diffuse pleural mesothelioma and asbestos exposure in the North Western Cape Province. British Journal of Industrial Medicine, 17, 260271.

Webster, I. (1965). Mesotheliomatous tumors in South 
Africa: Pathology and experimental pathology. Annals of the New York Academy of Sciences, 132, 623-646.

Webster, I. (1972). The pathology of asbestosis. In: Medicine in the Mining Industries, edited by J. M. Rogan, pp. 39-55. Heinemann Medical Books, London.

Wells, A. H. (1975). Asbestos in Duluth water. Minnesota Medicine, 58, 458-459.

Westlake, G. E., Spjut, H. J., and Smith, M. N. (1965). Penetration of colonic mucosa by asbestos particles. An electron microscopic study in rats fed asbestos dust. Laboratory Investigation, 14, 20292033.

Yazicioglu, S. (1976). Pleural calcification associated with exposure to chrysotile asbestos in Southeast Turkey. Chest, 70, 43-47.

Zolov, C., Bourilkov, T., and Babadjov, L. (1967). Pleural asbestosis in agricultural workers. Environ- is mental Research, 1, 287-292.

Requests for reprints to: Professor Y. I. Baris, Hacettepe University School of Medicine, Ankara, Turkey. 